\title{
Disposal of Uranium and Thorium Entering the Human Digestive System before Reaching the Blood by Adsorption on Simethicone and Forming a Non-absorbable Compound: A Full in vitro Analysis
}

\author{
Hamed Ibrahim Mira1, Nashat Mohamed Alanwar Abdalaty2,* \\ ${ }^{1}$ Professor of Geochemistry and Chairman of Nuclear Material Authority, Nuclear Materials Authority, Maadi, Cairo, EGYPT. \\ ${ }^{2}$ Department of Medicinal and Radiation Research, Nuclear Materials Authority, Maadi, Cairo, EGYPT.
}

\begin{abstract}
Introduction: This method was applied to form a non-absorbable complex with uranium and thorium swallowed with contaminated dust or other sources to get rid of them before absorption into the blood and discarded outside the body. A non-GIT absorbable simethicone was used in this method for the adsorption of uranium (VI) and thorium (IV) from a solution similar to the gastrointestinal tract $\mathrm{pH}$ medium. Materials and Methods: Accurately measured $9 \mathrm{mg}$ of pure standard uranyl nitrate and simethicone emulsion in concentration range $(100-300 \mathrm{mg})$ at $37 \pm 1^{\circ} \mathrm{C}$ for $20 \mathrm{~min}$ in $\mathrm{pH}$ ranges like the medium of the stomach and intestine then take the supernatant after centrifugation to make sure of decreasing of the concentration of uranium and thorium ions by ICP Mass Spectroscopy (ICP-MS). Results and Discussion: The data recorded for different total uranium and thorium concentrations reveal convergent behavior. Increasing simethicone concentration inside the safe dose shifts the sorption of uranium and thorium to $100 \%$ of the total concentration, calculated $t$ and $F$ values were compared with the reference method and the proposed method was equally precise and accurate. Conclusion: The data indicate that the method can successfully be applied for the complete adsorption of uranium and thorium on simethicone from GIT before reaching the blood.
\end{abstract}

Key words: Simethicone, Uranium, Thorium, Protection, Non-absorbable complex.

\section{INTRODUCTION}

Uranium and thorium are heavy metals with chemical toxicity and radioactivity, which causes progressive or irreversible renal injury and their compounds are potential carcinogens. ${ }^{1,2}$

Simethicone is a chemically inert drug that is not absorbed from the gastrointestinal tract ${ }^{3,4}$ used to relieve the symptoms of excessive gases in GIT., 50

Recently, a new type of inorganic- organic composite chelating adsorbent had been synthesized to selective laboratory adsorption. The composite adsorbents always contain a chelating agent and an inorganic particle matrix such as silica, smectite $^{8}$ and bentonite. ${ }^{9}$
Uranium dust content varies according to the type of the source, ${ }^{10-12}$ it was determined by complex formation using piroxicam, ${ }^{13}$ meloxicam, ${ }^{14}$ 2-(2- thiazolylazo)-p-cresol $(\mathrm{tac}),{ }^{15}$ arsenazo $\mathrm{iii}^{16}{ }^{16}$ 2-ethanolimino-2pentylidino-4-one, ${ }^{17}$ a mixture of - xylene and benzene, ${ }^{18}$ azide ions, ${ }^{19}$ acetylacetonate. ${ }^{20}$ Many procedures have been developed for determination of thorium including liquid-liquid extraction, ${ }^{21,22}$ ion-exchange resins, ${ }^{23,24}$ liquid membrane ${ }^{25}$ and solid phase extraction (SPE). ${ }^{26-29}$

According to U.S. Food and Drug Administration approval of simethicone, we were select it due to the safety on the human body and not need more tests on humans. ${ }^{30}$
Submission Date: 17-04-2020; Revision Date: 13-08-2020; Accepted Date: 23-11-2020

DOI: 10.5530/ijper.55.1.1 Correspondence: Dr. Nashat Mohamed Alanwar Abdalaty Lecture of Medicinal Chemistry and Pharmaceutical Science Nuclear Materials Authority, Maadi-530, Cairo, EGYPT. Phone: +201006782093 E-mail: nashat.alanwar@ yahoo.com

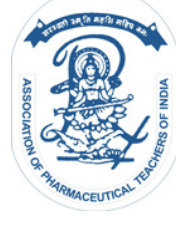

www.ijper.org 
Dust contaminated with uranium and thorium is one of the sources of the exposure of the human body to these radioactive materials by inhalation or ingestion. ${ }^{31,32}$ If uranium and thorium reached the blood it will be difficult to remove and will cause many diseases and physical problems. ${ }^{33,34}$

The main purpose of the present study is to find a way to prevent the absorption of uranium and thorium from the digestive tract to the blood and take them out of the body, simethicone was used for removal of uranium (VI) and thorium (IV) from GIT medium. The influences of time, $\mathrm{pH}$, amount of adsorbent and competitive substances on the sorption were investigated in details. The formed chelate may be due to the following mechanism (Scheme 1).

\section{MATERIALS AND METHODS}

\section{Materials and reagents working solution}

Chemicals used for the method were of the highest purity as available from their sources in the form of pure analytical grade.

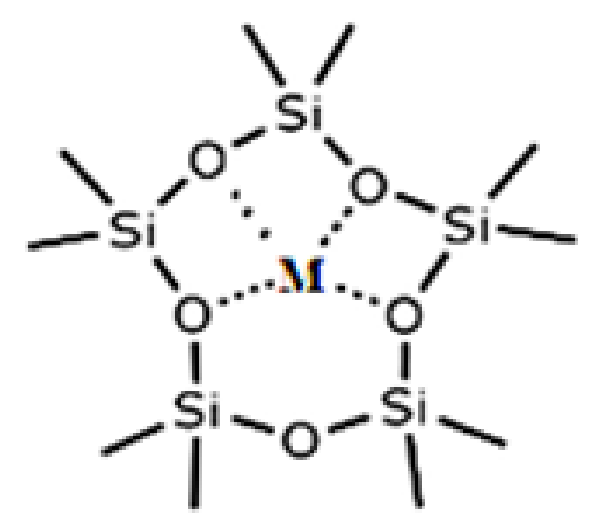

Scheme 1: A suggested structural mechanism of the formed chelation complex between simethicone and M (thorium or uranium)
1-Uranyl nitrate: $4 \mathrm{mgml}^{-1}$ solution in distilled water obtained from Fluka/Sigma-Aldrich (St. Louis, MO).

2-Thorium nitrate: $4 \mathrm{mgml}^{-1}$ solution in distilled water obtained from Sigma Chemical Co. (St. Louis, MO, USA)

3-Simethicone emulsion 2\%, USP 29, Amriya Pharm Industries.

\section{Methods}

Accurately measured $9 \mathrm{mg}$ of pure standard uranyl nitrate and thorium nitrate were transferred into a 25 $\mathrm{ml}$ volumetric flasks then add simethicone emulsion in concentration range (100 $-300 \mathrm{mg}$ ), the volumes were completed with distilled water and then immersed in a water bath at $37 \pm 1^{\circ} \mathrm{C}$ for $20 \mathrm{~min}$ for each $\mathrm{pH}$ from (1.5 to 3.5 ) like the medium of the stomach and from $(5.5-7.5)$ similar to the intestine medium with continuous stirring and the volume was adjusted with double distilled water to $25 \mathrm{ml}$. For each sample, the supernatant was separated from the adsorbent by centrifugation at $3000 \mathrm{xg}$ for $5 \mathrm{~min}$, then we took the supernatant liquid to make sure decreasing of the concentration of uranium and thorium ions by ICP Mass Spectroscopy (ICP-MS) at pH 1.5 - 7.5. The interference effect of pepsin, pancreatin, fatty acids (palmitic and oleic acid), amino acids (glycine, glutamine and arginine), monosaccharide's, lipase, proteases and amylases on this method had also been studied, uranium and thorium are a primary unit that will not be digested, as well as simethicone is not affected by digestive juices and is not absorbed. ${ }^{8,9}$ The proposed method was equally precise and accurate as of the reference one according to statistical analysis of the results, calculated $\mathrm{t}$ and $\mathrm{F}$ values were compared with the reference method ${ }^{35}$ to assessing the performance of the proposed method and showing no significant difference between them.

\begin{tabular}{|c|c|c|c|c|c|c|c|}
\hline \multirow[t]{2}{*}{ Uranium } & \multirow{2}{*}{$\begin{array}{l}\text { Simethicone } \\
\text { emulsion }\end{array}$} & \multicolumn{6}{|c|}{$\mathrm{pH}$} \\
\hline & & 1.5 & 2.5 & 3.5 & 5.5 & 6.5 & 7.5 \\
\hline $\begin{array}{l}\text { Taken } \\
\text { ppm }\end{array}$ & $\begin{array}{c}\text { Taken } \\
\mathrm{mg}\end{array}$ & \multicolumn{6}{|c|}{$\begin{array}{l}\text { Uranium } \\
\text { remaining in supernatant (ppm) }\end{array}$} \\
\hline 360 & 100 & 332 & 335 & 338 & 225 & 210 & 202 \\
\hline 360 & 150 & 167 & 167 & 165 & 160 & 145 & 135 \\
\hline 360 & 200 & 102 & 105 & 100 & 120 & 75 & 70 \\
\hline 360 & 250 & 38 & 36 & 35 & 33 & 10 & 9 \\
\hline 360 & 300 & 0 & 0 & 0 & 0 & 0 & 0 \\
\hline
\end{tabular}




\section{RESULTS AND DISCUSSION}

The previous procedure was applied to:

a- Insurance of complete adsorbance of uranium and thorium by back (ICP-MS) analysis of high concentrations of pure standard uranium and thorium (360 $\mu \mathrm{g} \mathrm{ml}^{-1}$ ) adsorbed on simethicone emulsion in concentration range (100 -300 mg) at different $\mathrm{pH} 1.5-$ 7.5 (Tables 1,2), the results obtained compared with the reference method ${ }^{35}$ are shown in (Tables 3,4). b- $360 \mu \mathrm{g} \mathrm{ml}^{-1}$ of uranium and thorium in presence of $10 \mu \mathrm{g} \mathrm{ml}^{-1}$ oleic acid, amino acids (glycine, glutamine and arginine), monosaccharide's, Lipases, Proteases and amylases, the results obtained are shown in (Tables 5,6). The experimental back (ICP-MS) determination of remaining uranium and thorium in the supernatant at different $\mathrm{pH}$ values indicate the complete adsorption of them on simethicone. The data recorded for different total uranium and thorium concentrations

\begin{tabular}{|c|c|c|c|c|c|c|c|}
\hline \multirow[t]{2}{*}{ Thorium } & \multirow[t]{2}{*}{ Simethicone emulsion } & \multicolumn{6}{|c|}{$\mathrm{pH}$} \\
\hline & & 1.5 & 2.5 & 3.5 & 5.5 & 6.5 & 7.5 \\
\hline $\begin{array}{l}\text { Taken } \\
\text { ppm }\end{array}$ & $\begin{array}{c}\text { Taken } \\
\text { mg }\end{array}$ & \multicolumn{6}{|c|}{$\begin{array}{l}\text { Thorium } \\
\text { remaining in supernatant (ppm) }\end{array}$} \\
\hline 360 & 100 & 300 & 331 & 340 & 220 & 215 & 198 \\
\hline 360 & 150 & 164 & 169 & 168 & 157 & 152 & 135 \\
\hline 360 & 200 & 100 & 109 & 102 & 115 & 78 & 69 \\
\hline 360 & 250 & 35 & 30 & 38 & 34 & 15 & 6 \\
\hline 360 & 300 & 0 & 0 & 0 & 0 & 0 & 0 \\
\hline
\end{tabular}

\begin{tabular}{|c|c|c|c|c|c|c|}
\hline \multirow{2}{*}{ Statistic } & \multicolumn{6}{|c|}{$\mathrm{pH}$} \\
\hline & 1.5 & 2.5 & 3.5 & 5.5 & 6.5 & 7.5 \\
\hline Mean recovery ${ }^{\star} \pm$ S.D. & $99.44 \pm 1.56$ & $99.68 \pm 0.87$ & $99.04 \pm 0.717$ & $99.7 \pm 0.717$ & $100.34 \pm 0.82$ & $99.82 \pm 0.63$ \\
\hline $\mathrm{N}$ & 5 & 5 & 5 & 5 & 5 & 5 \\
\hline Variance & 2.423 & 0.757 & 0.514 & 0.515 & 0.668 & 0.407 \\
\hline S.E & 0.695 & 0.389 & 0.32077 & 0.320 & 0.365 & 0.2853 \\
\hline$t$-test & 0.35 & 0.7 & 1.045 & 0.27 & 2.32 & 0.04 \\
\hline F-test & 6.3 & 1.83 & 1.999 & 1.05 & 1.28 & 2.00 \\
\hline Range of recovery (\%) & \multicolumn{6}{|c|}{$99.04-100.34$} \\
\hline
\end{tabular}

\begin{tabular}{l} 
Table 4: Statistical data for the adsorption of thorium nitrate on simethicon compared with the \\
reference method. \\
Statistic \\
\cline { 2 - 7 } \\
\cline { 2 - 7 }
\end{tabular}

(*) Average of three experiments 


\begin{tabular}{|c|c|c|c|}
\hline Table 5: Effect of some common ingredient in GIT, on the adsorption of uranium on simethicone. \\
\hline $\begin{array}{c}\text { Other Ingredients } \\
\text { 10 } \boldsymbol{\mu g} \text {. added }\end{array}$ & \multicolumn{2}{|c|}{ Uranium } \\
\cline { 2 - 4 } & $\begin{array}{c}\text { Taken } \\
\text { ppm }\end{array}$ & $\begin{array}{c}\text { Recovery } \\
\%\end{array}$ & pH \\
\hline - & 360 & 99 & 2.5 \\
pepsin & 360 & 98.7 & 2.5 \\
pancreatin & 360 & 99.8 & 2.5 \\
fatty acids & 360 & 101.5 & 7.5 \\
amino acids & 360 & 99.1 & 7.5 \\
monosaccharides & 360 & 99 & 7.5 \\
Lipases & 360 & 98.9 & 7.5 \\
Proteases & 360 & 99.3 & 7.5 \\
Amylases & 360 & 99.9 & \\
\hline
\end{tabular}

.(*) Average of three experiments

\section{Table 6: Effect of some common ingredient in GIT, on the adsorption of thorium on simethicone.}

\begin{tabular}{|c|c|c|c|}
\hline $\begin{array}{c}\text { Other Ingredients } \\
\text { 10 } \mathbf{\mu g} \text {. added }\end{array}$ & \multicolumn{3}{|c|}{ Thorium } \\
\cline { 2 - 4 } & $\begin{array}{c}\text { Taken } \\
\text { ppm }\end{array}$ & $\begin{array}{c}\text { Recovery* } \\
\%\end{array}$ & pH \\
\hline - & 360 & 99.2 & 2.5 \\
pepsin & 360 & 99.7 & 2.5 \\
pancreatin & 360 & 98.8 & 2.5 \\
fatty acids & 360 & 100.3 & 7.5 \\
amino acids & 360 & 98.1 & 7.5 \\
monosaccharides & 360 & 98 & 7.5 \\
Lipases & 360 & 99.7 & 7.5 \\
Proteases & 360 & 99.2 & 7.5 \\
Amylases & 360 & 99.6 & 7.5 \\
\hline
\end{tabular}

.(*) Average of three experiments

reveal convergent behavior. Increasing simethicone concentration inside the safe dose shifts the sorption of uranium and thorium to $100 \%$ of the total concentration (discussed further on). Simethicone drug was chosen as it is safe, non-GIT absorbed, very popular and low cost. The procedure is very simple, fast and the dose used for protection far from the maximum allowable dose (500 mg simethicone).

Therefore, according to the average time for digested food to start coming out the stomach (1-2) $\mathrm{hr},{ }^{36}$ we recommend that the worker exposed to contaminated dust take a half teaspoon $(\approx 2.5 \mathrm{ml})$ of Simethicone $2 \% \quad(\approx 50 \mathrm{mg})$ just before starting to exposure to contaminated dust and after $1 \mathrm{hr}$ of exposure. If the number of exposure hours exceeds, a half teaspoon is taken every $1 \mathrm{hr}$ with a maximum 10 doses per day within 10 working hours in order to not exceed the allowable dose/day (500mg). The optimization of sorption parameters was carefully studied depending on the duration time of uranium and thorium in the parts of the digestive system and the required degree of acidity as mentioned in the following paragraphs:

\section{Effect of heating temperatures}

GIT similar temperature $\left(37 \pm 1^{\circ} \mathrm{C}\right)$ was sufficient to achieve the goal of the complete adsorption of uranium and thorium on simethicone. Many temperatures were tried, the optimum temperature was from $25-50^{\circ} \mathrm{C}$ for uranium and $25-45^{\circ} \mathrm{C}$ for thorium at $\mathrm{pH} 5.5$ and 7.5 , (Figures 1 and 2).

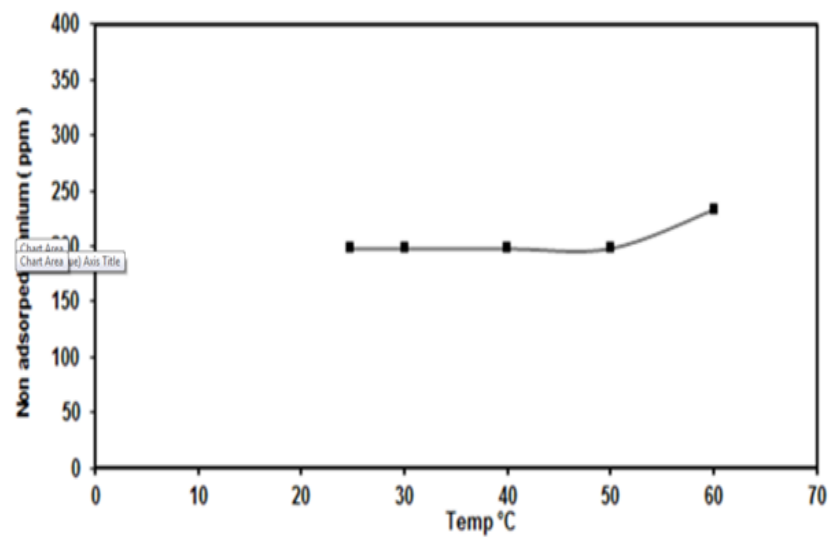

Figure 1: Effect of temperature on the adsorption of $360 \mathrm{ppm}$ uranium on $100 \mathrm{mg}$ simethocone at $\mathrm{pH} 5.5$ and 7.5 .

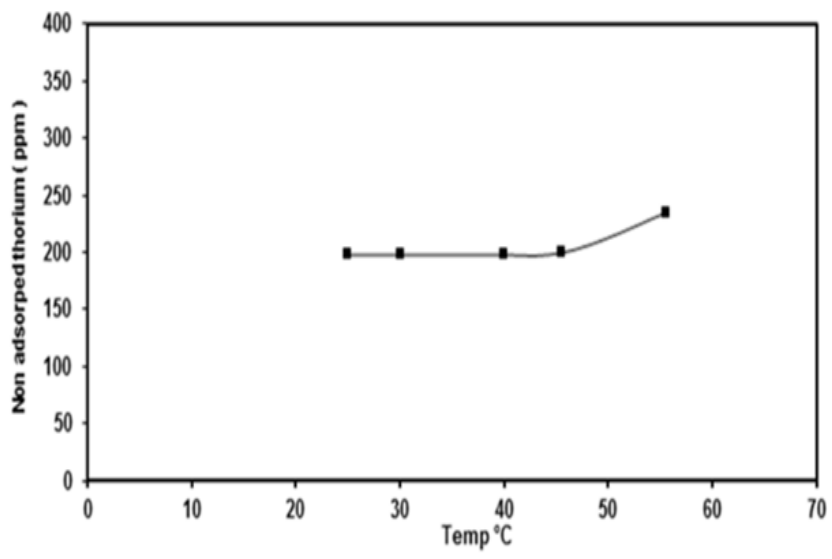

Figure 2: Effect of temperature on the adsorption of 360ppm thorium on $100 \mathrm{mg}$ siethicone at pH 5.5 and 7.5. 


\section{Effect of time}

The reaction was carried out at $37 \pm 1{ }^{\circ} \mathrm{C}$ and the adsorption complex formed was stable at $20 \mathrm{~min}$ to 17 $\mathrm{hr}$ for uranium and $15 \mathrm{hr}$ for thorium at $\mathrm{pH} 5.5$ (Figure 3 ), but at $\mathrm{pH} 7.5$ the complex was stable for more than $72 \mathrm{hr}$ for uranium and thorium (Figure 4).

\section{Effect of simethicone concentration}

It was found that $100 \mathrm{mg}$ ( 1 teaspoon) of $2 \%$ simethicone achieves a suitable concentration for the adsorption of uranium and thorium in the range of $(22-58 \mathrm{ppm})$ and (20-62 ppm) respectively along with the GIT parts, at very high concentration of uranium and thorium (360 $\mathrm{ppm}$ ) the $300 \mathrm{mg}$ (3 teaspoons or 1 tablespoon) of $2 \%$ simethicone were sufficient for full adsorption at different $\mathrm{pH}$, (Figures 5,6).

\section{Effect of $\mathrm{pH}$}

$\mathrm{pH}$ was carefully examined by studying the solutions similar to the gastrointestinal tract $\mathrm{pH}$ medium adjusted by adding $5 \% \mathrm{v} / \mathrm{v}$ of $\mathrm{HNO} 3$ or $5 \%$ of $\mathrm{v} / \mathrm{v} \mathrm{NH}_{4} \mathrm{OH}$ solutions between 1.5 to 7.5 , the results showed that, the adsorption efficiency slightly different with the

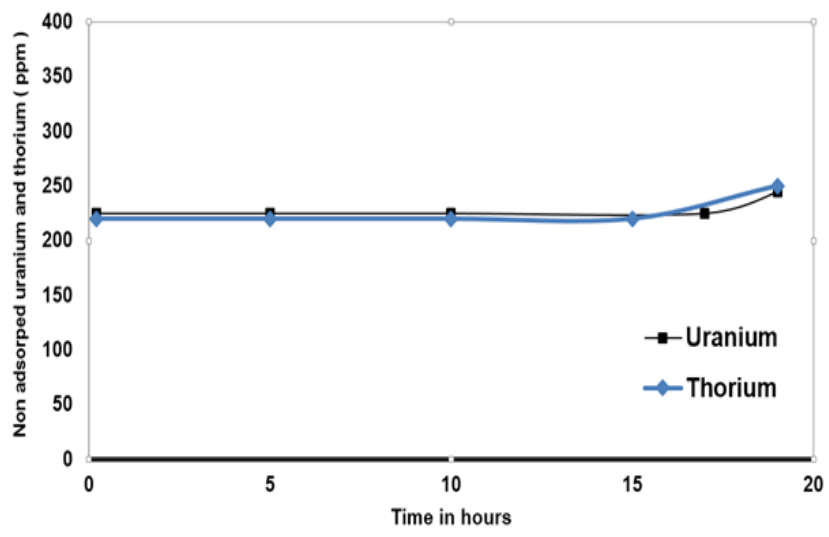

Figure 3: Effect of time on the adsorption of 360ppm uranium and thorium on $100 \mathrm{mg}$ simethicone at pH 5.5

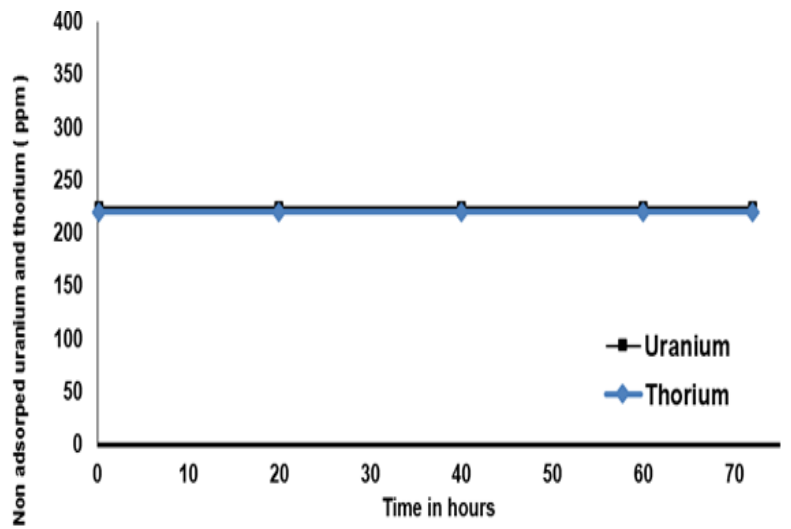

Figure 4: Effect of time on the adsorption of $360 \mathrm{ppm}$ uranium and thorium on $100 \mathrm{mg}$ simethicone at pH 5.5. change in $\mathrm{pH}$. At $\mathrm{pH} 1.5$, adsorption starts to slightly decreases but increases again at $\mathrm{pH} 5.5$, sorption still slightly increases to $\mathrm{pH} 7.5, \mathrm{pH} 1.5$ to 7.5 can be selected as optimum $\mathrm{pH}$ for uranium and thorium sorption on simethicone in GIT, (Figures 7,8) show the variation of the adsorption as a function of $\mathrm{pH}$ values.

\section{Interference Study}

To study the effect of GIT enzymes and digested products as pepsin, pancreatin, lipase amylases, proteases, fatty acids (palmitic and oleic acid), amino acids (glycine, glutamine and arginine) and monosaccharide's on the adsorption of uranium and thorium, The test was applied to each substance on its acidic medium, the data demonstrate that no effect of this compound on expelling these dangerous metals from the digestive tract.

\section{Linearity and quantification}

An inverse linear relationship was obtained in back (ICP-MS) measurement between simethicone concentration and supernatant concentration of remaining uranium and thorium (Figures 5,6).

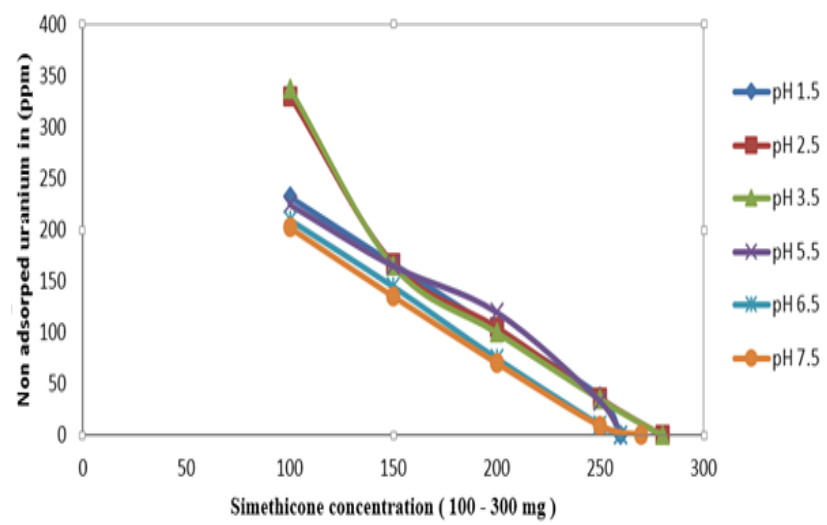

Figure 5: Effect of simethicone concentration (100-300 mg) on the adsorption of uranium at different $\mathrm{pH}(1.5 .-7.5)$.

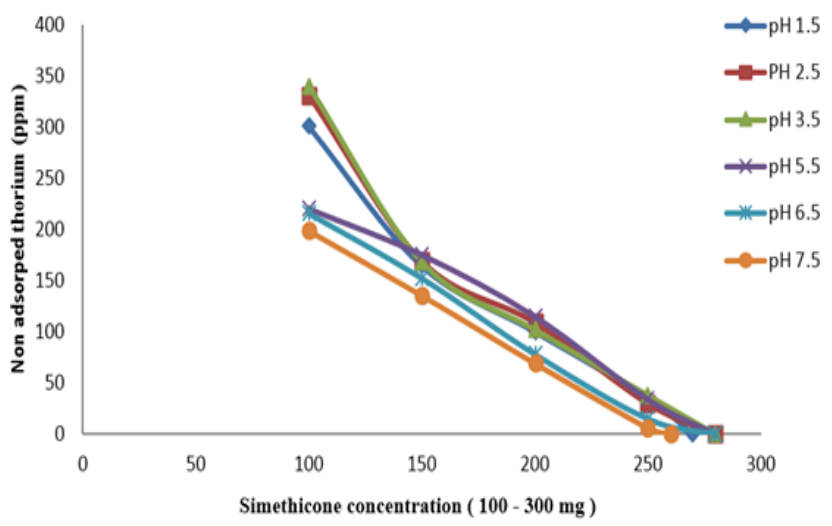

Figure 6: Effect of simethicone concentration (100 - $300 \mathrm{mg})$ on the adsorption of thorium at different $\mathrm{pH}(1.5 .-7.5)$. 


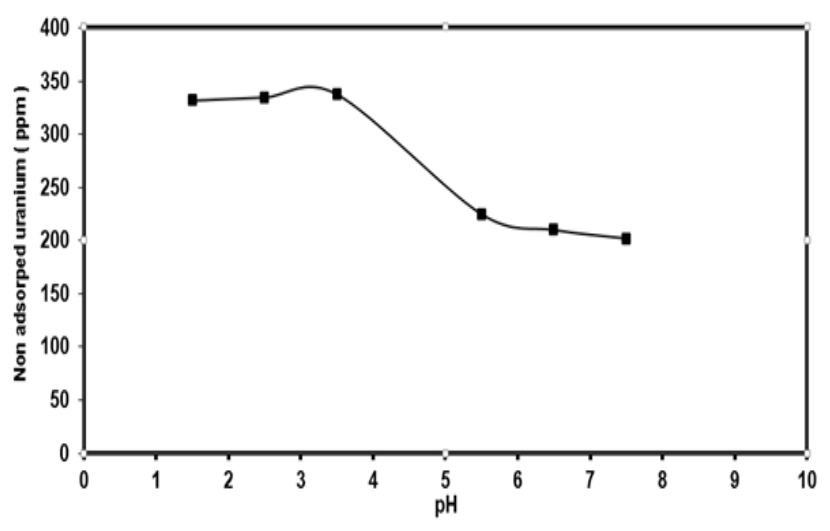

Figure 7: Effect of $\mathrm{pH}$ on the adsorption of 360ppm uranium on $100 \mathrm{mg}$ simethicone.

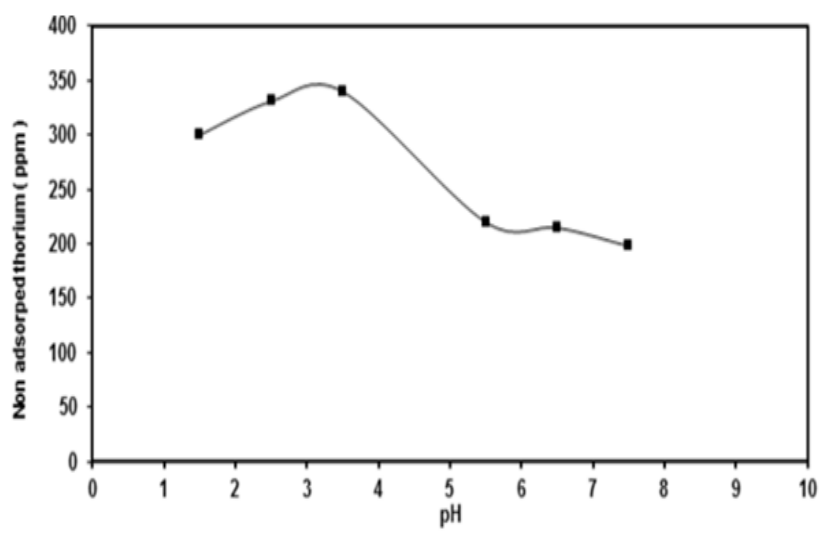

Figure 8: Effect of $\mathrm{pH}$ on the adsorption of $360 \mathrm{ppm}$ Thorium on $100 \mathrm{mg}$ simethicone.

The proposed method was equally precise and accurate as of the reference one according to the statistical analysis of the results of the three replicate determination values under the same conditions for each sample analysis. Accuracy and precision were indicated by calculating $t$ and $F$ values which were less than the tabulated ones indicating that there was no significant difference between the proposed and reference method ${ }^{35}$ (Tables 3,4). The small SE indicate excellent precision and accuracy, recovery experiments were performed by adding a known amount of the enzymes and digestion units of food. No interference from the common additives was observed in the results (Tables 5,6) as an additional confirmation of accuracy and precision. The good linearity of the calibration graph and the negligible scatter of the experimental points were clearly evident from the value of the variance. Therefore, the method is useful for the disposal of uranium and thorium entering the human digestive system before reaching the blood.

\section{CONCLUSION}

The proposed method was successfully applied for the complete adsorption of uranium and thorium on simethicone from GIT before reaching the blood, The method is successful in the various acidic medium along the digestive tract, The data was assessed by comparing the calculated $t$ and $F$ values with the reference method ${ }^{35}$ Tables 3,4, the results showed no significant difference between them. In (Tables 5,6) the results obtained show that pepsin, pancreatin, lipase, amylases, proteases, fatty acids (palmitic and oleic acid), amino acids (glycine, glutamine and arginine) and monosaccharide's do not interfere. Statistical analysis of the results revealed that the proposed method was more precise and accurate than the reference one.

\section{ACKNOWLEDGEMENT}

The corresponding author acknowledges Nuclear Materials Authority for facilitating the research work.

\section{CONFLICT OF INTEREST}

The authors report no conflicts of interest.

\section{ABBREVIATIONS}

GIT: Gastro Intestinal Tract; ICP-MS: ICP Mass Spectroscopy.

\section{REFERENCES}

1. Ayata S, Aydinci S, Merdivan M, Binzet G, Kulcu N. Sorption of uranium using silica gel with benzoylthiourea derivatives. J Radioanal Nucl Chem. 2010;285(3):525-9.

2. Memon JR, Hallam KR, Bhanger MI, Turki AE, Allen GC. Evaluation of sorption of uranium onto metakaolin using X-ray photoelectron and Raman spectroscopies. Anal Chim Acta. 2009;631(1):69-73.

3. Holtmann G, Gschossmann J, Mayr P, Talley NJ. A randomized placebocontrolled trial of simethicone and cisapride for the treatment of patients with functional dyspepsia Aliment Pharmacol. Ther. 2002;16(9):1641-8.

4. Kaplan MA, Prior MJ, Ash RR, McKonly KI, Helzner EC, Nelson EB. Loperamide-simethicone vs loperamide alone, simethicone alone and placebo in the treatment of acute diarrhea with gas-related abdominal discomfort. A randomized controlled trial. Arch Fam Med. 1999;8(3):243-8.

5. Yusuf YS, Long OX. Addition of simethicone to polyethylene glycol electrolyte solution for bowel preparation improves colonoscopy bowel visualization: A review. Biomedical Letters. 2016;2(1):24-30.

6. Food and Drug Administration. Over-the-counter drugs: Proposal establishing a monograph for antacid products. Fed Regist. 1973;8714-24

7. Qu RJ, Zhang Y, Sun CM, Wang $\mathrm{CH}$, Ji CN, Chen $\mathrm{H}$. Adsorption of $\mathrm{Hg}(\mathrm{II})$ from an aqueous solution by silica-gel supported diethylenetriamine prepared via different routes: Kinetics, thermodynamics and isotherms. J Chem Eng. 2010;55(4):1496-504.

8. Zhang WH, Ding YJ, Boyd SA, Teppen BJ, Li H. Sorption and desorption of carbamazepine from water by semectite clays. Chemosphere. 2010;81(7):954-60.

9. Toor M, Jin B. Adsorption characteristics, isotherm, kinetics and diffusion of modified natural bentonite for removing diazo dye. Chem Eng J. 2012;187:7988.

10. EINahas HA, EIFeky MG, Mira, HI. Mineralogy, M-type tetrad effect and radioactivity of altered granites at the $\mathrm{G}$. Abu Garadi shear zone, central Eastern Desert, Egypt. Chinese Jor of Geochem. 2011;30(2):153-64. 
11. Cheira MF, Mira HI, Sakr AK, Mohamed SA. Adsorption of U(VI) from acid solution on a low-cost sorbent: Equilibrium kinetic and thermodynamic assessments. Nucl Sci and Techniques. 2019;30(156):2-18.

12. ElHameed AAH, Eweda WE, Abou-Taleb KA, Mira HI. Biosorption of uranium and heavy metals using some local fungi isolated from phosphatic fertilizers. Annals of Agricultural Sci. 2015;60(2):345-51.

13. Lutfullah K, Farheen R, Nafisur R, Syed NH. Spectrophotometric determination of uranium (VI) via complexation with Piroxicam. Indian Journal of Chemical Technology. 2009;16(5):437-41.

14. Lutfullah K, Mohd NA, Nafisur R, Syed NH. Optimized and validated spectrophotometric method for the determination of uranium (VI) via complexation with meloxicam. Journal of Hazardous Materials. 2008;155(12):261-8.

15. Leonardo SG, Antonio CSC, Sergio LCF, Maria LF, Marcelo SC. Spectrophotometric determination of uranium using 2-(2-thiazolylazo)-pcresol (tac) in the presence of surfactants. J Braz Chem Soc. 1999;10(6):51922.

16. Ali N, Nahid G, Mohammad G, Ali E. Simultaneous spectrophotometric determination of uranium and thorium using arsenazo iii by h-point standard addition method and partial least squares regression. Journal of the Chinese Chemical Society. 2007;54(2):411-8.

17. Adel SO, Adel E, Medhat AS, Alaa EA. Spectrophotometric determination of fe(iii), cu(ii) and uo2(ii)ionsby a new analytical reagent derived from condensation of monoethanolamine and acetyl acetone. Bulletin of the Chemists an Technologists of Macedonia. 2005;24(1):11-9.

18. Singh NSB, Mohan SV. A spectrophotometric method for uranium determination. Journal of Radio analytical and Nuclear Chemistry. 1979;52(2):319-27.

19. DoCarmo DR, DeAndrade JF, Guimares OM. Spectrophotometric determination of uranium through uranyl/azide system. Analytical Letters. 1995;28(10):1897-911.

20. Tabushi M. Spectrophotometric determination of uranium by solvent extraction as acetylacetonate. Bulletin of the Institute for Chemical Research. 1995;37(4):237-44.

21. Mohamed A, Didier V, Omar A, Abdelkrim A. Liquid-liquid extraction of thorium (IV) by fatty acids: A comparative study. Journal of Radio analytical and Nuclear Chemistry. 2014;299(3):1191-8.

22. Nasab ME. Solvent extraction separation of uranium (VI) and thorium (IV) with neutral organophosphorus and amine ligands. Fuel. 2014;116:595-600.

23. Poirier RH, Calkins GD, Lutz GA, Bearse AE. Ion exchange separation of uranium from thorium. Industrial and Engineering Chemistry. 1958;50(4):6136.

24. Kwang L, Dan AL, Aleksandar NN. The effectiveness of ion exchange resins in separating uranium and thorium from rare earth elements in acidic aqueous sulfate media. Part 1. Anionic and cationic resins. Hydrometallurgy. 2017; 174:147-55.

25. Saeed A, Milani F, Zahakifar A. Continuous bulk liquid membrane technique for thorium transport: Modeling and experimental validation. Journal of the Iranian Chemical Society. 2019;16(3):455-64.

26. Emily RU, Jennifer MC, Steve $\mathrm{JH}$. Determination of uranium and thorium in natural waters with a high matrix concentration using solid-phase extraction inductively coupled plasma mass spectrometry. Chimica Acta. 2001;442(1):141-6.

27. Sibel B, Arzu E, Adil D, Rıdvan S. Selective separation of thorium using ion imprinted chitosan-phthalate particles via solid phase extraction. Separation Science and Technology. 2007;41(14):3109-21.

28. Daneshvar G, Jabbari A, Yamini Y, Paki D. Determination of uranium and thorium in natural waters by ICP-OES after on-line solid phase extraction and pre-concentration in the presence of 2,3-dihydro-9,10-dihydroxy-1,4antracenedion. Journal of Analytical Chemistry. 2009;64(4):602-8.

29. Preetha R, Mary J, Prasada T. Solid phase extractive preconcentration of thorium onto 5,7-dichloroquinoline-8-ol modified benzophenone. Talanta. 2002;58(4):701-9.

30. U.S. Food and Drug Administration, center for drug evaluation and research. 1998. Application No., 20-773 (NDA 20773).

31. Jiljana ML, Danica V, Marija G, Jankulovica G, Manojlovicae D. The human biomonitoring study in Serbia: Background levels for arsenic, cadmium, lead, thorium and uranium in the whole blood of adult Serbian population. Ecotoxicology and Environmental Safety. 2019;169:402-9.

32. Colman R, Alexander B. The effect of lanthanides and actinides on blood coagulation. ii. Assay of a new serum thromboplastic factor vulnerable to these elements and its variations in health and disease. Journal Clinical Investigation. 1964;43(4):720-7.

33. Yantasee WT, Sangvanich J, Creim A, Pattamakomsan K, Wiacek RJ, Fryxell GE. Functional sorbents for selective capture of plutonium, americium, uranium and thorium in blood. Health Phys. 2010;99(3):413-9.

34. Kurttio P, Harmoinen A, Saha H, Salonen L, Karpas Z, Komulainen H, Kidney toxicity of ingested uranium from drinking water. American Journal of Kidney Diseases. 2006;47(6): 972-82.

35. Ito S, Takaku $\mathrm{Y}$, Ikeda M, Kishimoto $\mathrm{Y}$. Determination of trace levels of uranium and thorium in high purity gadolinium sulfate using the ICP-MS with solid-phase chromatographic extraction resin. Progress of Theoretical and Experimental Physics. 2017; 2017(11):113H01.

36. Proano M, Camilleri M, Phillips SF, Brown ML, Thomforde GM. Transit of solids through the human colon: Regional quantification in the unprepared bowel. J Physiol Gastrointest Liver Physiol. 1990;258(6):856-62.

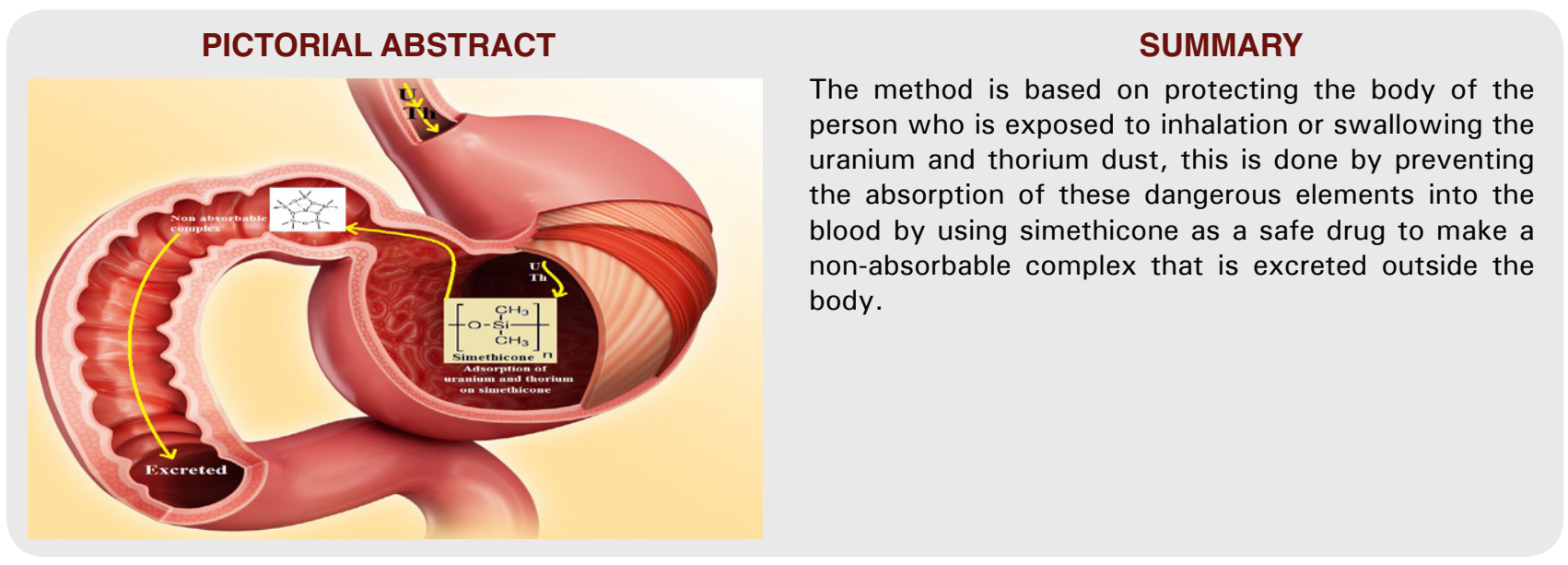

Cite this article: Mira HI, Abdalaty NMA. Disposal of Uranium and Thorium Entering the Human Digestive System before Reaching the Blood by Adsorption on Simethicone and Forming a Non-absorbable Compound: A Full in vitro Analysis. Indian J of Pharmaceutical Education and Research. 2021;55(1):146-52. 